TEME, г. XLIV, бр. 1, јануар - март 2020, стр. 17-32

Оригинални научни рад $\quad$ https://doi.org/10.22190/TEME191114006R

Примљено: 14. 11. 2019.

UDK 341.645:347.426.4

Ревидирана верзија: 27. 1. 2020.

Одобрено за штампу: 20. 2. 2020.

\title{
STATE LIABILITY FOR NON-PECUNIARY DAMAGES IN THE JURISPRUDENCE OF THE EUROPEAN COURT OF HUMAN RIGHTS ${ }^{a}$
}

\author{
Zoran Radivojević", Nebojša Raičević \\ University of Niš, Faculty of Law, Niš, Serbia \\ zoranr@prafak.ni.ac.rs
}

\begin{abstract}
Non-pecuniary damages are a form of just satisfaction that the ECtHR may award if a violation of protected rights is found. These damages can be claimed by individuals, groups of persons, non-governmental organizations and states, whereby the awarded amount must be distributed to individual victims. However, for the Court to award compensation for non-pecuniary damage, several requirements must be met. The Court has awarded compensation for non-pecuniary damage on several grounds, such as pain, stress, anxiety, frustration, embarrassment, humiliation, and loss of reputation. Unfortunately, the criteria for determining the amounts of compensation for moral damage are still not clear and precise, so they have been determined by the Court on an equitable basis, taking into account its case-law standards.
\end{abstract}

Key words: non-pecuniary damage, ECtHR, injured party, grounds for damages, amount of compensation.

\section{ОДГОВОРНОСТ ДРЖАВА ЗА НЕМАТЕРИЈАЛНУ ШТЕТУ У ЈУРИСПРУДЕНЦИЈИ ЕВРОПСКОГ СУДА ЗА ЉУДСКА ПРАВА}

\begin{abstract}
Апстракт
Надокнада нематеријалне штете представља један облик правичног задовољења који ЕСЉП може досудити уколико установи кршење заштићених права. Ту надокнаду могу тражити појединци, групе лица, невладине организације и државе, с тим што државе добијени износ морају расподелити индивидуалним жртвама. Међутим, да би Суд досудио надокнаду нематеријалне штете, мора да буде испуњено неколико услова. Суд је досуђивао надокнаду нематеријалне штете по више основа, као што су бол, стрес, узнемиреност, фрустрација, осрамоћење, понижавање и губи-
\end{abstract}

${ }^{a}$ This paper is the result of research on the project "Harmonization of Serbian Law with European Union Law", funded by the Faculty of Law, University of Niš. 
так угледа. Нажалост, још увек не постоје јасни и прецизни критеријуми за утврђивања износа одштета, тако да их је Суд одређивао на правичној основи, водећи рачуна о стандардима из своје праксе.

Кључне речи: нематеријална штета, ЕСЉП, оштећена страна, основи за одштету, износ надокнаде.

\section{INTRODUCTION}

According to Art. 41 of the European Convention of Human Rights (ECHR or Convention), "if the Court finds that there has been a violation of the Convention or the Protocols thereto, and if the internal law of the High Contracting Party concerned allows only partial reparation to be made, the Court shall, if necessary, afford just satisfaction to the injured party". Raison d'être of just satisfaction is "directly derived from the principles of public international law relating to State liability" (Cyprus v. Turkey, GC, Just Satisfaction, §40), and its aim is to put the injured person "in the same legal position as it would be if his/her Convention rights had not been violated" (Jakšić, 2006, pp. 465). Although Art. 41 did not specify the forms of just satisfaction, the European Court of Human Rights (ECtHR or Court) has awarded just satisfaction under the following three grounds: pecuniary damages, non-pecuniary damages, and the costs and expenses.

In this paper, the authors will only analyze compensation for nonpecuniary damage, as a form of just satisfaction. Non-pecuniary (moral, nonmaterial) damage is harm to personal or immaterial goods, such as life, health, freedom, honor, reputation, etc., as well as damage to tangible goods, causing harm not only to these goods, but also to their owner or user (Radišić, 2018, pp. 220). Therefore, moral damages compensate injuries that are not economic in nature.

The principle of non-pecuniary damage compensation was established in the ECtHR's practice in the Vagrancy cases, but it was awarded for the first time in the case of Ringeisen. Since then, in its well established case-law, the Court has built the rules concerning subjects who may claim compensation for moral damage, requirements and grounds for awarding this type of damages, as well as the determination of its amount. These issues are the subject of the research hereinafter.

WHO MAY CLAIM REPARATION FOR NON-PECUNIARY DAMAGE?

Since the term "injured party" is a synonym for "victim" in the context of Art. 41 of the Convention (Dijk, Hoof, Rijn, \& Zwaak, 2006, pp. 258), everyone entitled under the ECHR to lodge an application may also claim just satisfaction. Accordingly, the compensation for nonpecuniary damage arising from the infringement of the rights guaranteed by the Convention may be sought by individuals, groups of persons, nongovernmental organizations, and states. 


\section{INDIVIDUALS AND GROUP OF PERSONS}

Any person may bring an application against a State Party that has allegedly violated his/her right guaranteed by the ECHR, regardless of the person's nationality, place of residence or legal capacity (Zehentner v. Austria, §39). In most cases, applications are lodged and the compensation for moral damage is claimed by the direct victims of the violation of the Convention rights. Direct victims are directly and personally affected by acts or omissions of state authorities.

Non-pecuniary damages may also be claimed by indirect victims. These victims are personally affected by an infringement of another person's human rights. They are not directly impacted by a violation of their personal rights, rather they are indirectly affected by a violation of someone else's rights. ${ }^{1}$ Indirect victims are very often close relatives, who experience suffering, worry, distress and discomfort, due to the direct victim's infringement. However, they do not automatically acquire the status of indirect victims nor the right to lodge an application with the ECtHR. These persons will have locus standi if their suffering outweighs what is usual or unavoidable when a family member is exposed to a breach of human rights (Orhan v. Turkey, §358).

The ECtHR allows relatives to seek compensation for moral damage when a direct victim has died prior to taking his/her case before this Court. A good example of this situation is the case of Ramsahai, where it accepted the joint application of the grandparents and father of the boy killed by the police. The Court found that the official investigation into the death of the boy had been inadequate, and thereby found a breach of Art. 2 of the ECHR. Because of such a violation, the ECtHR awarded the applicants jointly $20,000 €$ with respect to non-pecuniary damage.

The ECtHR also accepted applications of close relatives and awarded them non-pecuniary damages in the event of the disappearance of a person. The Kurt case may be quoted as an example. The application was brought by Mrs. Kurt, both on her own behalf and on behalf of her son, who had disappeared during a military operation of the Turkish forces. The Court found that, due to the disappearance of her son and the failure of the authorities to conduct an effective investigation into his disappearance, there was a violation of Art. 3, and thereby awarded the mother $£ 10,000$ for a nonpecuniary loss. The Court emphasized that in these situations, the violation of Art. 3 was not based on the mere act of a person's "disappearance", but rather on the authorities' non-response. ${ }^{2}$

\footnotetext{
${ }^{1}$ In this situation the Court awards non-pecuniary damages not to the "injured party", but to the party who was allowed to pursue the application (Altwicker-Hámori, Altwicker \& Peters, 2016, pp. 15).

${ }^{2}$ E.g., Utsayeva \& Others v. Russia, $§ 185$.
} 
Besides parents and children, the Court also awarded compensation to close relatives (Ibragimov and Others v. Russia), spouses (Utsayeva \& others v. Russia), and even non-marital partners of the deceased direct victims. ${ }^{3}$ In doing so, the ECtHR noted that for obtaining the status of indirect victim, it is not relevant whether the applicants were the heirs of the deceased (disappeared) person (Van Colle v. UK, §86).

The Court has also awarded compensation for moral damage to close relatives in cases where the deceased person was subject to torture (Keenan v. UK). On the other hand, ECtHR "has consistently rejected as inadmissible ratione personae applications lodged by the relatives of deceased persons in respect of alleged violations of rights other than those protected by Articles 2 and 3 of the Convention" (Gradinar v. Moldova, $\S 91$ ), as they belong to the category of non-transferable rights (Bic \& Others v. Turkey, §22).

A specific situation exists when an applicant who has already lodged an application dies during the proceedings. The Strasbourg institutions pointed out that in such a situation the heirs of the deceased applicant did not have "a general right that the examination of an application should be continued". In several cases, the Court rejected to continue the proceedings, justifying such a decision on the fact that the "application is closely linked to the person of the deceased applicant" (Franz Mathes v. Austria, §19). In contrast, in some other cases the ECtHR allowed the heirs to continue the proceedings and awarded them the compensation for moral damage claimed by the deceased applicant (X. v. France, §54).

Finally, non-pecuniary damages may also be claimed by a "group of individuals" made up of a number of people connected with a certain common interest. The ECtHR bundles such complaints in one case if applicants may demonstrate that they all have been affected by the same breach of the ECHR. For example, in the Guerra case, which was initiated by 40 citizens of the town Manfredonia, the Court found that due to the releasing of toxic substances from a chemical factory near the town, Art. 8 was infringed and awarded each applicant 10 million lira.

\section{NON-GOVERNMENTAL ORGANIZATIONS}

Non-pecuniary damages can also be claimed by non-governmental organizations. This term covers legal entities and only those of a private character, i.e. which do not exercise any governmental powers. A wide range of private organizations have submitted applications to the ECtHR and sought compensation for moral damage, such as companies, trade unions, churches, associations, newspapers, and political parties. In contrast,

\footnotetext{
${ }^{3}$ Velikova v. Bulgaria.

${ }^{4}$ E.g., Richard Kofler v. Italy, §16; Franz Mathes v. Austria, §18.
} 
locus standi before ECtHR do not have the central organs of the State and decentralized authorities that exercise "public functions", regardless of their autonomy vis-à-vis the central organs; likewise, it applies to local and regional authorities (Radio France \& Others v. France, §26).

There have been difficulties in accepting the right of legal persons, especially companies, to claim reparation for non-pecuniary losses. The ECtHR initially expressed doubts that commercial companies could suffer non-pecuniary damage (Manifattura FL v. Italy, §22), but later on it accepted such a possibility (Comingersoll S.A. v. Portugal, GC, §35).

\section{STATES}

Art. 33 empowers any State Party to refer to the ECtHR in case of an alleged breach of the Convention by another Contracting Party. There are two categories of applications lodged under this article. Firstly, a State may allege a violation of the Convention in abstracto, complaining about the general shortcomings in another State. In other types of inter-State complaints, the applicant State points out the concrete human rights violations of its own or foreign nationals.

Very few inter-State applications have been filed to date (only 24, 8 of which are still in process). The ECtHR has dealt with non-pecuniary damage in only 3 cases. The first case was Ireland $v$. UK, but without going into the merits of non-pecuniary damages since Ireland clarified that it did not seek any just satisfaction ( $\$ 245)$.

In the case Cyprus v. Turkey, the Court essentially grappled with the issue of non-pecuniary damage in inter-State proceedings. In its judgment on the merits, the Court merely stated that "the issue of the possible application of Article 41 of the Convention was not ready for decision and postponed its consideration," while in the judgment adopted in 2014, for the first time in its history, it afforded the compensation for moral damage in inter-State disputes (Cyprus v. Turkey, GC, Just satisfaction). In that judgment, the ECtHR firstly examined the timeliness of the Cypriot claim for just satisfaction and concluded that it was not out of time (\$23-30). The Court then examined whether the application of Art. 41 is possible in inter-State proceedings. Referring to the public international law principle expressing that States are obliged to make reparation for breaches of treaty obligations, the ECtHR stated that "Article 41 of the Convention does, as such, apply to inter-State cases" (\$40-43). However, the Court added that just satisfaction can only be sought if proceedings are instituted in order to protect an individual's interests, while this is not possible in cases initiated for the protection of collective interests. If the Court awards just satisfaction in inter-State cases, it does not belong to a State, but to individual victims $(\$ 46)$.

In the said judgment, the ECtHR awarded Cyprus with lump sums of $30,000,000 €$ for non-pecuniary damage suffered by the surviving relatives of the 1,456 missing persons, and $60,000,000 €$ to the enclaved 
residents of the Karpas peninsula. The Court indicated that these amounts should be distributed by the Cypriot Government to individual victims, under the supervision of the Committee of Ministers.

The ECtHR awarded non-pecuniary damage in inter-State disputes for the second time in the case Georgia v. Russia. In the main judgment, the ECtHR found that the Russian Federation had violated Art. 3, 5 and 13 of the ECHR and Art. 4 of the Protocol $4 .^{5}$ Thereafter, Georgia submitted a claim for just satisfaction and the Court decided that Russia must pay the sum of 10 million euros in respect of non-pecuniary damage suffered by a group of at least 1,500 Georgian nationals (Georgia v. Russia (I), GC, Just Satisfaction). Contrary to the case of Cyprus v. Turkey, this time the Court gave instructions to the applicant State on how to distribute the afforded lump sum. However, it should be noted that Turkey and Russia have not paid the sums ordered by the ECtHR yet.

\section{REQUIREMENTS FOR AWARDING NON-PECUNIARY DAMAGES}

According to Art. 41 of the Convention, Rule 60 of the Rules of Court and the case-law, compensation for non-pecuniary damage will be awarded if the following criteria are met:

1. the applicant submitted a claim;

2. the ECtHR found that there was a violation of the Convention or the Protocols thereto;

3. there is a causal link between the violation of the rights and the damage;

4. there is an injured party;

5. the respondent State legal system allows only partial reparation;

6. the ECtHR considers it necessary to afford non-pecuniary damages.

If the above-mentioned criteria are met, the ECtHR may award non-pecuniary damage. It can decide on this issue in the judgment on merits, i.e. at the same time as finding the breach of the ECHR. If the issue is not ready for a decision at that moment, the Court shall adjourn and resolve it in a separate judgment.

\section{COMPENSATION CLAIM}

The Court does not award reparation for non-pecuniary losses on its own motion, but only if the applicant submits such a claim (Rules of Court, Rule 60). The plaintiff must specify the requested amount, but does not

\footnotetext{
${ }^{5}$ The case concerned the expulsion of over 4,600 Georgian nationals from the territory of Russia in autumn 2006, some of whom were also detained and subjected to inhuman and degrading treatment.
} 
have to provide any proof of the moral damage suffered (Gridin v. Russia, $\S 20)$. If the applicant considers that they are the victim of multiple right violations, they may seek either separate amounts for each alleged violation or a single lump sum covering all the violations (Practice Direction, §15). That claim has to be made within the time limit set by the Court, otherwise it will be rejected. Thus, in deciding on non-pecuniary damage, the ECtHR generally respects the principle of non ultra petita.

However, in some situations, the Court departed from this principle. Therefore, it granted higher non-pecuniary damages than those requested by the applicant. For example, in the case of Stradovnik v. Slovenia, the Court awarded the applicant $6,400 €$, although he claimed only $5,000 €(\S 23$, 25). Also, ECtHR compensated for moral damage when the claim was submitted after the given deadline (Davtian v. Georgia, §68-71).

In some cases, the ECtHR made awards of damages even though the applicant did not seek it at all. The Court did so when it found a violation of Art. 3, "since this right has an absolute character", but with the remark that such a decision was "exceptional" by character (Chember v. Russia, §77). The Court acted in a similar manner in the case of Rusu v. Austria, concerning the breach of Art. 5. Noting the "fundamental importance of that right," the ECtHR granted the applicant with 3,000€, although no claim for just satisfaction had been submitted (\$62).

\section{VIOLATION OF THE CONVENTION}

A violation of one of the rights guaranteed by the Convention or its Protocols is conditio sine qua non for awarding non-pecuniary damages. Therefore, in order to obtain compensation, it is necessary that the Court establishes that the decision or measure taken by the conflicts with the Convention obligations. Therefore, compensation for moral damage is only awarded when there is state liability for the breaches of guaranteed rights (Jakšić, 2006, p. 470).

If the applicant invoked a violation of several rights, it is sufficient that the Court declares the violation of at least one of them (Enea v. Italy, $\S 159)$. On the other hand, if the Court does not find a violation of any right, the claimant will not be entitled to redress. Certainly, non-pecuniary damages cannot be afforded to complaints declared inadmissible at the earlier stages of the proceedings (Schabas, 2016, p. 836).

\section{CAUSAL LINK}

In order to obtain moral damages, the plaintiff must demonstrate a clear causal link between the violation of rights and the harm suffered. In contrast, the Court is not satisfied by "a merely tenuous connection between the alleged violation and the damage, nor by mere speculation as to what might have been" (Practice Direction, §7). 
In determining the causal link in violation of Art. 6, the Court does not take into account the so-called hypothetical causality. It is irrelevant for the ECtHR what the outcome of the procedure before the national authority would be if there had been no procedural failure in domestic proceedings. For example, in the case of Kostovski v. the Netherlands, the defendant State contested the existence of a sufficient causal link between the violation of Art. 6 (examinations of anonymous witnesses without the possibility of the accused to ask questions and challenge the witnesses' statements) and the applicant's conviction. The State claimed that the applicant would have been convicted in spite of the possibility of questioning the witnesses. However, the Court did not accept this argument, stating that "detention was the direct consequence of the establishment of his guilt, which was effected in a manner that did not comply with the requirements of Article 6" (\$48).

\section{INJURED PARTY}

An injured party is a person whose guaranteed rights have been violated and who has suffered damage. The term "injured party" is similar to the term "victim" used in the Art. 34 of the Convention. In the context of Art. 41 "these two words must be considered as synonymous" (Vagrancy, Art. 50, §23), because every "injured party" is at the same time a "victim."

However, in the context of Art. 34, there was a difference between these terms, given that the existence of the Convention violation was conceivable even in the absence of prejudice to the applicant. "Harm was not seen as a prerequisite for a finding of a violation, while an injured party was a victim of an infringement who had suffered prejudice" (Ichim, 2015, pp. 70). That little difference between the two terms disappeared after Protocol 14 entered into force, introducing "significant disadvantage" as an additional admissibility criterion (Altwicker-Hámori et al., 2016, pp. 14). After that novelty, every applicant has to prove the significant harm suffered in order to pass the admissibility test.

\section{PARTIAL REPARATION IN NATIONAL LAW}

The ECtHR awards non-pecuniary damages merely if the liable State's legal system provides only a partial reparation to the injured party. On the basis of argumentum a minore ad maius, the same applies to a situation when the national law foresees no remedy for the suffered damages at all (Bydlinski, 2011, pp. 40). Therefore, in order to award damages for non-pecuniary losses, it is necessary that the internal law foresees incomplete non-pecuniary damages or foresees no remedy at all (Practice Direction, §1). This requirement is an expression of the principle of subsidiarity in the Strasbourg regime of reparation (Ichim, 2015, pp. 67).

However, if the injured person received the full compensation at the national level, the Court has no competence to afford any amount in 
addition to this sum (Bydlinski, 2011, pp. 43). In other words, the Court cannot award just satisfaction which exceeds the full reparation for the damages suffered. It can be concluded that the European system of human rights protection does not recognize "punitive damages" aiming to punish responsible states and deter future violations of human rights, but only applies "compensatory damages" with the aim to compensate the actual worth of the damage suffered (Bydlinski, 2011, pp. 41). ${ }^{6}$

Regarding this condition, it is questionable whether the applicant must attempt to obtain compensation at the national level before seeking the ECtHR to award just satisfaction. Some respondent states argued that the applicant must exhaust all domestic remedies related not only to the initial application filed under Art. 34, but also to the applicant's compensation claim. In contrast, both the ECtHR ${ }^{7}$ and scholars (Dijk at al., 2006 pp. 258; Ichim, 2015, pp. 69-70; Reid, 2004, pp. 547; Jakšić, 2006, pp. 470) consider that the local remedies exhaustion rule does not apply to just satisfaction claims, as this would impede the effective protection of human rights.

\section{NECESSITY TO AFFORD NON-PECUNIARY DAMAGES}

The ECHR does not guarantee victims the right to obtain redress. The award in respect of non-pecuniary loss is not an automatic consequence of the Court's finding that the protected right has been violated (Steiner, 2011, pp. 10), but the ECtHR enjoys "a certain discretion in the exercise of that power, as the adjective 'just' and the phrase 'if necessary' attest" (Comingersoll S.A. v Portugal, GC, §29) to that. In other words, there is no entitlement of a victim to the award of just satisfaction as their subjective right, but only as a possibility thereof (Ichim, 2015, pp. 176).

Therefore, even in situations where internal law allows only partial compensation, the Court will not always award moral damages to the injured party. It will do so only "if necessary". As the ECtHR explains, "the awarding of sums of money to applicants by way of just satisfaction is not one of the Court's main duties, but is incidental to its task of ensuring the observance by States of their obligations under the Convention" (Sylla v. the Netherlands, §72).

The ECtHR did not specify in its judgments when just satisfaction is necessary. Some scholars assert that the Court should define some clear and objective guidelines for applying the necessity principle (Ichim, 2015, pp. 76).

\footnotetext{
${ }^{6}$ This was confirmed by the ECtHR itself, noting that Art. 41 of the Convention "does not provide a mechanism [...]for imposing punitive sanctions on the respondent State" (Varnava and Others v. Turkey, §156).

${ }^{7}$ E.g., Vagrancy, Art. 50, §16; Philis v. Greece (No. 2), §59; Ramsahai and Others v. the Netherlands, §443.
} 


\section{GROUNDS FOR NON-PECUNIARY DAMAGE COMPENSATION}

The Convention does not enumerate the reasons (grounds) on the basis of which the compensation for non-pecuniary damage may be awarded. In the absence of such a provision, it is left to the Court to decide the issue on a case-to-case basis. On the one hand, there are judgments in which the compensation for non-pecuniary damage was awarded without any closer explanation or with a very brief and lapidary reasoning. The Court found it sufficient only to state in these judgments "that the violation of human rights caused non-pecuniary damage to be compensated" (Kutić v. Croatia, §39), without mentioning the specific basis for compensation.

However, in most of the cases, the Court did find it necessary and useful to mention or list the reasons why it decided to award compensation for pecuniary damage. In these instances, it usually did not confine itself to just one basis, but cited two or more reasons, not acting in the same manner even then. One of the Court's formulations was that non-pecuniary damage was intended to make "reparation for the state of disasters, inconvenience and uncertainty resulting from the violation in question" (Comingersoll S.A. v Portugal, GC, §29; Arvanitaki-Roboti and Others v. Greece, §27). Elsewhere, the Court found that the applicant suffered "anguish and distress," "pain and mental distress" or "stress and frustration" (Katsiyeva \& Others v. Russia, §173).

The Court has also defined compensation for non-pecuniary damage as "reparation for anxiety, inconvenience and uncertainty caused by the violation" (Driza v. Albania, §131). Reference has also been made to "helplessness and frustration," "powerlessness and frustration," "frustration and feeling of injustice" (Galich v. Russia, §43). Furthermore, the Court has held that the award for non-pecuniary damage may include elements in respect of the following: "psychological harm or trauma," "embarrassment and humiliation," "loss of reputation" and "loss of relationship" (Leach, 2005, pp. 404). Finally, the Court has identified situations where the applicant had concurrently "suffered trauma, whether physical or psychological, pain and suffering, distress, anxiety, frustration, feeling of injustice or humiliation, prolonged uncertainty, disruption to life, or real loss of opportunity" (Varnava \& Others v. Turkey, §224).

However, in its jurisprudence so far, the Court has neither explained nor defined any of the aforementioned reasons for awarding non-pecuniary damage compensation. Due to the absence of definitions of the terms used, it is very difficult to systematize or classify the bases for this type of compensation. Yet, with a certain degree of simplification, and based on the criteria of their nature, they could be grosso modo divided into two large groups. The first would be the reasons which are mainly the result of a violation of the victim's bodily integrity due to a breach of the Convention. They are usually manifested in the form of pain or physical suffering, caused by bodily injury. The second, a far more numerous group 
of grounds, are the consequences of the victim's mental integrity violations. Therefore, here, the matter is not about bodily harm, but rather a violation of mental health, honor, reputation and the dignity of the victim.

Nevertheless, it should be noted that it is not often possible to draw a clear distinction between the two groups of bases. The main reason for this is that the violation of bodily integrity, in addition to physical, also regularly causes psychological consequences, both in relation to the victim and to members of their immediate family or close relatives. On the other hand, this distinction can only be made with regard to individuals, i.e. natural persons as victims of the Convention violations.

With regard to legal persons, the situation is rather different. With these entities, the grounds for the award of non-pecuniary damages are of a different nature and mainly concern the violation of moral, business or political integrity of the persons concerned. However, initially, the Court doubted that legal persons could suffer non-pecuniary damage because they "cannot feel "anxiety" or "distress" like natural persons" (Altwicker-Hámori et al., 2016, pp. 15). Later on, the Court admitted that companies and other legal persons may suffer non-pecuniary damage. The Court held that "account should be taken of company's reputation, uncertainty in decisionplanning, disruption in the management of the company [...] and lastly the anxiety and inconvenience caused to the members of management team" (Comingersoll SA v. Portugal, GC, §35). The Court even acknowledged that not only commercial companies, but also political parties and their members may suffer non-pecuniary damage. Thus, it awarded compensation for these damages in cases of prohibition of work and dissolution of political parties, due to the feeling of disappointment or frustration of the party members and its founders (Dicle on behalf of the Democratic Patry (DEP) v. Turkey, §78).

\section{DETERMINING THE AMOUNT OF COMPENSATION}

Pertaining to the compensation for non-pecuniary damage, a particular problem is the determination of its amount. There are no clear and precise criteria in the Convention or other documents of the Court for calculating the amount of compensation. In this respect, based on Art. 41 of the Convention, the Court enjoys a wide margin for appreciation (Ђаjић, 2014, pp. 199-200). Therefore, it can be said that the determination of the amount of "compensation for non-pecuniary damage by the European Court of Human Rights is difficult to understand other than the subjective judgment of the moral values of the victim and the perpetrator of the injury" (Shelton, 2015, pp. 324).

The absence of firm criteria in determining the amount of compensation was explicitly acknowledged by the Court itself. According to the Practice Direction, "it is in the nature of non-pecuniary damage that it does not lend itself to precise calculation" (§14). The Court has pointed out several times that "non-pecuniary damage is the applicant's subjective 
measure of distress he had endured because of the violation of his rights and by his nature is not amenable to proof' (Korchagin v. Russia, §25).

The second important standpoint in the Courts jurisprudence is that "respective domestic practice of assessing compensation for non-pecuniary damage is not building" (Kissling et al., 2011, pp. 622). Nevertheless, domestic case-law can have limited relevance to the question of nonpecuniary damage in proceedings before Court (Gault v. UK, §30). The calculation criteria of the domestic courts can "offer assistance but should not be considered as prevailing" or mandatory "criteria offered in the Court" (Kissling et al., 2011, pp. 623).

On the other hand, according to its Practice Direction, the Court makes its assessment of damage for non-pecuniary loss as "having regard to the standards which emerge from its case-law" (§14). "Although AngloAmerican stare decisis doctrine does not govern the jurisprudence of the Court" (Altwicker-Hámori et al., 2016, pp. 21), it has a limited duty to follow its previous judgments when calculating the amount of nonpecuniary damage. In particular, "it must take into account in its assessment of the amounts already awarded in similar cases" (Arvanitaki-Roboti \& Others v. Greece, GC, §32). The Court has recently started to set up tables or scales on past awards in respect of non-pecuniary damage, stating average sums, grouped on the basis of respondent States and violated rights" (Altwicker-Hámori et al., 2016, pp. 21). The problem is that the Court has not so far published any table or scale.

The respondent State and the applicant can reach an agreement on the amount of the compensation in respect of non-pecuniary damage. In that case, the agreed amount will be awarded by the Court. However, "an agreement by the Government with an applicant cannot be a model in other similar cases” (Segerstedt-Wiberg \& Others v. Sweden, §125).

As pointed out in its Practice Direction, the Court "makes its assessment of damage for non-pecuniary loss [...] on an equitable basis" (§14). The principle of equity is the general and guiding principle in the prevailing number of cases. The basic element of equity is that the award in respect of the non-pecuniary damage "involves flexibility and an objective consideration of what is just, fair and reasonable in all circumstances of the case" (Al-Skeini \& Others v. UK, §182).

Apart from these explicit or implicit general rules of assessment, there are a few concrete criteria for assessing damages for non-pecuniary loss. From an analysis of the case-law the following criteria may be identified: the seriousness of the violation of the Convention, the seriousness and duration of the injury, personal characteristics and conduct of the applicant, and economic circumstances in the applicant's country.

The first and most important criteria in the calculation of nonpecuniary damage is the seriousness of the Conventions violation. The level of seriousness can be explained by the "implicit hierarchy of 
Convention rights according to their relative importance". The hierarchy of the rights, "starting with the right to life (Art.2) and the prohibition of torture (Art.3), may suggest their importance" (Altwicker-Hámori et al., 2016, pp. 18). The Court itself has referred to Art. 2 together with Art. 3, as it "enshrines one of the basic values of democratic societies making up the Council of Europe" (Al-Saadoon \& Mufdbi v. UK, §118).

The second criteria for assessing damages for non-pecuniary loss are the seriousness and duration of the injury. The Court uses several formulations to qualify the injury as particularly serious. For example, the Court may state that the applicant must have sustained "exceptional" or "significant" harm (Mocanu \& Others v. Romania, GC, §371) or that they must have suffered "considerably" or suffered "serious" pain (Dimitrov \& Others v. Bulgaria, §174). In addition, the duration of the injury has a bearing on its seriousness. Examples for such extended injures are extended unlawful deprivation of liberty (Stork v. Germany, §34) or excessive length of criminal proceeding in a rape case (N.D. v. Slovenia, §127).

The Court also takes personal characteristics into account when calculating the amount of non-pecuniary damage. The Court has relied on the following characteristics: the age of the applicant (Kostovska v. FYR Macedonia, §60), the state of health of the applicant (Iatridis v. Greece, GC, §46) or the applicant's important judicial status (Zubko \& Others v. Ukraine, §74). Furthermore, the Court also takes into consideration the applicant's behavior. "It may award less of the amount of compensation in case where the applicant bears some degree of responsibility for the actual damage" (Schabas, 2016, p. 837). The Court also may reduce the amount of non-pecuniary damage because of "contributory negligence" by the victim (Practice Direction, §2).

Finally, the sum awarded in respect of non-pecuniary damage depends on the economic circumstances in the applicant's country. States have different price levels and standards of living. Based on the criteria of the "local economic circumstances" (Basarba OOD v. Bulgaria, §26), the Court awarded different sums for non-pecuniary damage in similar cases.

\section{CONCLUDING REMARKS}

Art. 41 of the Convention allows victims of human rights violations to receive non-pecuniary damages as a form of just satisfaction. However, victims do not have the right to compensation, but only the right to seek it from the Court. It is the ECtHR that finally decides whether any compensation is necessary, enjoying broad discretion in that process. Unfortunately, up to now, the Court has not established any criteria for determining the necessity of compensation, so the award of non-pecuniary damage is left to the subjective assessment of the judges. There are no exact criteria for calculating the amount of compensation, thus they are 
determined voluntarily on the basis of equity, taking into account the standards established in its case-law. The consequence of such treatment is an inconsistent and non-uniform jurisprudence of the ECtHR.

The purpose of awards on non-pecuniary damages has been limited to mere compensation for the losses caused to the applicant. The Court has adopted a compensatory approach to non-pecuniary damages as it is not intended to punish the Contracting Party responsible. The Court has considered it inappropriate to accept claims for "punitive," "aggravated" or "exemplary" damages, therefore showing its reluctance to open the "Pandora's box" for the possible spreading of punitive damages.

\section{REFERENCES}

Al-Saadoon and Mufdbi v. UK, 61498/08, 2. 3. 2010.

Al-Skeini \& Others v. UK, 55721/07, 7.7.2011.

Altwicker-Hámori, S., Altwicker, T., \& Peters, A. (2016). Measuring Violations of Human Rights: An Empirical Analysis of Awards in Respect of Non-Pecuniary Damage under the European Convention on Human Rights, Zeitschrift für ausländisches öffentliches Recht und Völkerrecht, 76, 1-51.

Arvanitaki-Roboti \& Others v. Greece, (GC), 27278/03, 15. 2. 2008.

Basarba OOD v. Bulgaria, 77660/01, 20. 1. 2011.

Bic \& Others v. Turkey, 55955/00, 2. 2. 2006.

Bydlinski, F. (2011). Methodological Approaches to the Tort Law of the ECHR, In: A. Fenyves, E. Karner, H. Koziol \& E. Steiner (Eds.), Tort Law in the Jurisprudence of the European Court of Human Rights, (pp. 29-128). Berlin: De Gruyter.

Chember v. Russia, 7188/03, 3. 7. 2008.

Comingersoll S.A. v. Portugal, (GC), 35382/97, 6. 4. 2000.

Cyprus v. Turkey, (GC), 25781/94, Merits 10. 5. 2001 and Just Satisfaction 12. 5. 2014.

Davtian v. Georgia, 73241/01, 27.7.2006.

De Jong, Baljet \& van den Brink v. the Netherlands, 8805/79, 8806/79; 9242/81, 22. 5. 1984.

De Wilde, Ooms and Versyp v. Belgium ("Vagrancy"), (Art. 50), 2832/66; 2835/66; 2899/66, 10.3.1972.

Dicle on behalf of the Demicratic Patry (DEP) v. Turkey, 25141/94, 10. 12. 2002.

Dijk, P., Hoof. F., Rijn. A., \& Zwaak., L. (2006). Theory and Practice of the European Convention on Human Rights. Oxford: Intersentia.

Dimitrov \& Others v. Bulgaria, 77938/11, 1. 7. 2014.

Driza v. Albania, 33771/02, 13. 11. 2007.

Ђајић, С. (2014). Накнада нематеријалне штете у поступку пред Европским судом за људска права: Кипар против Турске [Remedies for Moral Damage before the European Court of Human Rights: Cyprus v. Turkey Case]. Зборник радова Правног факултета у Новом Саду 48(3). 189-206. doi:10.5937/zrpfns48-6970.

Enea v. Italy, 74912/01, 17. 9. 2009.

Franz Mathes v. Austria 12973/87, Report of the Commission, 13. 1. 1992.

Galich v. Russia, 33307/02, 13. 5. 2008.

Gault v. UK, 1271/05, 20. 11. 2007.

Georgia v. Russia (I), (GC), 13255/07, Merits 3.7.2014 and Just Satisfaction 31.1.2019.

Gradinar v. Moldova, 7170/02, 8. 4. 2008.

Gridin v. Russia, 4171/04, 1. 6. 2006.

Guerra \& Others v. Italy, (GC), 14967/89, 19. 2. 1998. 
Iatridis v. Greece, (GC), 31107/96, 19. 10. 2000.

Ibragimov \& Others v. Russia, 34561/03, 29. 5. 2008.

Ichim, O. (2015). Just Satisfaction under European Convention on Human Rights. Cambridge: Cambridge University Press.

Ireland v. UK, 5310/71, 18. 1. 1978.

Jakšić, A. (2006). Evropska konvencija o ljudskim pravima - komentar [European Convention on Human Rights - Commentary]. Beograd: Pravni fakultet.

Katsiyeva \& Others v. Russia, 5108/02, 17. 1. 2008.

Keenan v. UK, 27229/95, 3. 4. 2001.

Kissling, C., \& Kelliher, D. (2011). Compensation for Pecuniary and Non-Pecuniary Loss, In: A. Fenyves, E. Karner, H. Koziol \& E. Steiner (Eds.), Tort Law in the Jurisprudence of the European Court of Human Rights, (pp. pp. 579-724). Berlin: De Gruyter.

Korchagin v. Russia, 19798/04, 1. 6. 2006.

Kostovska v. FYR Macedonia, 44353/02, 15. 6. 2006.

Kostovski v. the Netherlands, 11454/85, 20. 11. 1989.

Kurt v. Turkey, 24276/94, 25. 5. 1998.

Kutić v. Croatia, 48778/99, 2. 1. 2002.

Leach, Ph. (2017). Taking a Case to the European Court of Human Rights, Oxford: Oxford University Press.

Manifattura FL v. Italy, 12407/86, 27. 2. 1992.

Mocanu \& Others v. Romania, (GC), 10865/09; 45886/07; 32431/08, 17. 9. 2014.

N.D. v. Slovenia, 16605/09, 15. 1. 2015.

Practice Direction, Just Satisfaction Claims, 28 March 2007.

Radio France \& Others v. France, 53984/00, Decision of 23.9.2003 and Judgment of 30. 3. 2004.

Radišić, J. (2018). Obligacion pravo [Law of Obligations]. Niš: Pravni fakultet.

Ramsahai \& Others v. the Netherlands, 52391/99, 10. 11. 2005.

Reid, K. (2004). A Practitioner's Guide to the European Convention on Human Rights. London: Sweet\&Maxwell.

Richard Kofler v. Italy, 8261/77, Report of the Commission, 9. 10. 1982.

Ringeisen v. Austria (Article 50), 2614/65, 22. 6. 1972.

Rusu v. Austria, 34082/02, 2. 10. 2008.

Schabas, W. A. (2016). The European Convention on Human Rights: A Commentary. Oxford: Oxford University Press.

Segerstedt-Wiberg \& Others v. Sweden, 62332/00, 6. 6. 2006.

Shelton, D. (2015). Remedies in International Humanitarian Law, Oxford: Oxford University Press.

Société Colas Est \& Others v. France, 37971/01, 16. 4. 2002;

Steiner, E. (2011). Just Satisfaction under Art 41 ECHR: A Compromise in $1950-$ Problematic Now. In: A. Fenyves, E. Karner, H. Koziol \& E. Steiner (Eds.), Tort Law in the Jurisprudence of the European Court of Human Rights, (pp. 3-26). Berlin: De Gruyter.

Stork v. Germany, 61602/00, 16. 6. 2005.

Stradovnik v. Slovenia, 24784/02, 13. 4. 2006.

Sylla v. the Netherlands, 14683/03, 6. 7. 2006.

Utsayeva \& Others v. Russia, 29133/03, 29. 5. 2008.

Van Colle v. UK, 7678/09, 13. 11. 2013.

Varnava \& Others v. Turkey, (GC), 16064-16066/90, 16068-16073/90, 18. 9. 2009.

Velikova v. Bulgaria, 41488/98, 18. 5. 2000.

X. v. France, 18020/91, 31. 3. 1992.

Zehentner v. Austria, 20082/02, 16. 7. 2009.

Zubko \& Others v. Ukraine, 39557/04; 5622/04; 8538704; 11418/04, 24. 4. 2006. 


\title{
ОДГОВОРНОСТ ДРЖАВА ЗА НЕМАТЕРИЈАЛНУ ШТЕТУ У ЈУРИСПРУДЕНЦИЈИ ЕВРОПСКОГ СУДА ЗА ЉУДСКА ПРАВА
}

\author{
Зоран Радивојевић, Небојша Раичевић \\ Универзитет у Нишу, Правни факултет, Ниш, Србија
}

\section{Резиме}

Накнада нематеријалне (моралне, неимовинске) штете представља један од облика правичног задовољења из чл. 41 „Европске конвенције о људским правима”. Одговорност држава за ову врсту штете, која иначе није изричито предвиђена у наведеном члану, установљена је кроз дугогодишњу и богату јуриспруденцију Европског суда за људска права. Том приликом Суд је изградио посебна правила која се тичу субјеката овлашћених да траже надокнаду нематеријалне штете, услова за досуђивање те врсте штете, основа за надокнаду и утврђивање висине њеног износа.

Нематеријалну одштету могу тражити појединци, групе лица, невладине организације и државе. У највећем броју случајева, надокнаду нематеријалне штете захтевају директне жртве кршења права из Конвенције, али то могу тражити и индиректне жртве које су погођене кршењем нечијих туђих права. Кад су у питању државе, њихова је обавеза да добијени износ расподеле индивидуалним жртвама.

Да би Суд досудио надокнаду нематеријалне штете, мора да буде испуњено неколико услова. Према слову Конвенције и Пословника Суда, као и постојећој јуриспруденцији, они се састоје у следећем: да је апликант поднео захтев; да је Суд утврдио постојање повреде Конвенције или протокола; да постоји узрочна веза између повреде права и настанка штете; да постоји оштећена страна; да правни систем тужене државе дозвољава само делимичну накнаду и да Суд сматра потребним да досуди нематеријалну одштету.

У Конвенцији нису енумеративно набројани основи због којих Суд може досудити надокнаду нематеријалне штете. У одсуству једне такве одредбе, остављено је да то питање у сваком конкретном случају решава са̂м Суд. У досадашњој пракси Суд је досуђивао нематеријалну одштету по више основа, као што су бол, стрес, узнемиреност, фрустрација, осрамоћење, понижавање, разочараност, губитак угледа и изгледа или прекид везе.

Посебан проблем је тај што у Конвенцији и другим документима Суда не постоје јасни и прецизни критеријуми за израчунавање висине накнаде. Суд је до сада одређивао износ накнаде на правичној основи, водећи рачуна о стандардима из своје и националне праксе. Поред тога, узимао је у обзир и неке посебне критеријуме, као што су озбиљност кршења Конвенције, озбиљност и временско трајање повреде, личне особине и понашање подносиоца захтева и економске прилике у држави подносиоца захтева. 